IRA International Journal of Management \& Social Sciences

ISSN 2455-2267; Vol.08, Issue 02 (August 2017)

Pg. no. 200-205

Institute of Research Advances

http://research-advances.org/index.php/RAJMSS

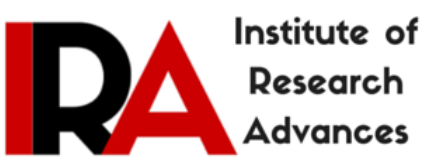

\title{
Implementation of Public Works in Greater Warangal Municipal Corporation
}

\section{Dr. Mattewada Chandrakala}

Lecturer, Government College for Girls, Narsampet

Warangal Rural, Telangana, India.

Type of Review: Peer Reviewed.

DOI: http://dx.doi.org/10.21013/jmss.v8.n2.p7

\section{How to cite this paper:}

Chandrakala, M. (2017). Implementation of Public Works in Greater Warangal Municipal Corporation. IRA-International Journal of Management \& Social Sciences (ISSN 2455-2267), 8(2), 200-205. doi:http://dx.doi.org/10.21013/jmss.v8.n2.p7

(C) Institute of Research Advances.

\section{(cc) BY-NC}

This work is licensed under a Creative Commons Attribution-Non Commercial 4.0 International License subject to proper citation to the publication source of the work.

Disclaimer: The scholarly papers as reviewed and published by the Institute of Research Advances (IRA) are the views and opinions of their respective authors and are not the views or opinions of the IRA. The IRA disclaims of any harm or loss caused due to the published content to any party.

Institute of Research Advances is an institutional publisher member of Publishers Inter Linking Association Inc. (PILA-CrossRef), USA. The institute is an institutional signatory to the Budapest Open Access Initiative, Hungary advocating the open access of scientific and scholarly knowledge. The Institute is a registered content provider under Open Access Initiative Protocol for Metadata Harvesting (OAI-PMH).

The journal is indexed \& included in WorldCat Discovery Service (USA), CrossRef Metadata Search (USA), WorldCat (USA), OCLC (USA), Open J-Gate (India), EZB (Germany) Scilit (Switzerland), Airiti (China), Bielefeld Academic Search Engine (BASE) of Bielefeld University, Germany, PKP Index of Simon Fraser University, Canada. 


\begin{abstract}
A majority of the slum households in Warangal are working as labourers. The slums lack infrastructure facilities such as roads, drainage, housing, electricity, basic education and health, etc. With the implementation of programmes like Swarna Jayanthi Sahari Rozgar Yojana (SJSRY), the community based organizations like neighborhood groups and neighborhood committees have taken roots and they have been participating in the poverty alleviation and other development programmes effectively. Spread of slums across the city is contributing to unhygienic environment in terms of cleanliness, water stagnation, presence of vectors, etc., which increases vulnerability towards deceases. Living conditions of the poor have consistently deteriorated due to several factors like inadequate environmental infrastructure and basic services. This research article to be discussed the problems and prospects of Implementation of Public Works Programmes in Greater Warangal Municipal Corporation.
\end{abstract}

Key Words: Urban Development, Administrative System, Infrastructure facilities; driven technology renewable resources

\title{
Introduction
}

"It's extremely troubling to see, when you have examples like union officials say there is not enough money going to public works yet they have teachers collect salaries from districts they don't even work for, Vernuccio said. This does not help the taxpayer at all. i think that is why we are starting to see a push back in general.

- Prof. Greg Mourad

Warangal Municipality is one of the oldest Municipalities in Telangana. It was constituted as major Municipality in 1344 Fasli. The first election was held on adult franchise in 1952 under Hyderabad Municipal and Town Committees Act, 1951 and a committee was constituted. It was upgraded as Special Grade Municipality in July 1959 and into a Selection Grade Municipalities in July 1960 and declared as Municipal Corporation on August 18, 1994. On 19 March 2013,G.O.Ms.No.99 was issued and Merged and inclusion of areas covered in the surrounding forty two (42) Gram Panchayats into the limits of Warangal Municipal Corporation. On 28 Jan 2015, G.O.MS.No.40 issued and declared Greater Warangal Municipal Corporation. Warangal is the Headquarters of Dist. of the same name and is situated between 9 latitude of $18^{\prime}-4^{\prime \prime}$ north and of $79^{\circ}-4^{\prime}-28^{\prime \prime}$ cost longitude on the Chennai Delhi sections of the South Sectoral Railway at an altitude of about $900 \mathrm{Ft}$. above the sea level. Warangal city is a centre of Education both academic and professional courses and a place of growing interest for a keen historian, an enthusiastic Geologist, an ambitious archaeologist and a curious pilgrim to explore more and more the Historical movements, a variety of geological formations and the ancient temples available in and around the city.

\section{Greater Warangal as a City of World Heritage}

Replacing the actual city infrastructures is often unrealistic in terms of cost and time. However, with recent advances in technology, we can infuse our existing infrastructures with new intelligence, digitize and connect our systems, so they can sense, analyze and integrate data, respond intelligently to the needs. Thus, keeping a bird's eyeview and better data analysis leads to better decisions. For example-The high concentration of mobility during the rush hour underlines the importance of a better utilisation of existing infrastructural networks in an innovative way. In the years ahead there will be more and more traffic on the roads. Road widening and new roads cannot compensate for the growth. To permanently improve circulation, the entire infrastructure must be better utilised. One strategic approach to reducing congestion is to apply collected data and a systems view to encourage increased use of public transport.

Telangana has become the 29th state of India and city of Hyderabad is its capital. Hyderabad, known for its heritage with modernity like "Ganga Jamuna Tahjeeb" has several tourist attractions like the Charminar, Mecca Masjid, Golconda Fort, Hussainsagar Lake, Birla Mandir, Chowmahalla Palace, Salar Jung Museum., Birla Temple 
etc. Hyderabad also has a rare distinction of being ranked as the 2nd best place in the world to visit in year 2015 by the National Geographic Traveler magazine December 2014 issue. Other important tourist places in Telangana include, Warangal from where the Kakatiyas ruled has tourist attractions such as Warangal Fort, Thousand Pillar Temple, Kakatiya Kalathoranam, Ramappa Temple, Laknavaram Lake etc. Bhongir Fort, Nagarjunsagar Dam and Yadagirigutta Temple located in Nalgonda District also attract many tourists. Adilabad District known for its pristine nature also has Gnana Saraswati Temple at Basar, Kuntala Waterfall and Kawal Wildlife Sanctuary. (Now Tiger Reserve) Other famous temples Vemulawada Temple, Kondagattu are located in Karimnagar District which also has Lower Maner dam (boating). Sri Sita Ramachandra Swamy Temple at Bhadrachalam, Medak Church Pillala Marri (Largest Banyan Tree) at Mahabubnagar are some other places a tourist can visit Alampur Jogulamba Temple in Mahbubnagar Dist. Which is 5th shaktipeetas of 18 well known shaktipeetahs in India.

After discussing the theoretical framework of planned urban development and international standard of cities we find that India is lacking in long term planning. Our cities are in dole drums. In the present chapter the basic components of urban issues i.e. drainage, sewerage, water supply, roads, solid waste management and street lights related to Aligarh city have been discussed at length. Before that an insight about location, geography, topography, population and problems faced by Aligarh city has been discussed. As Greater Warangal Municipal Corporation (GWMC) has added another cap in its feather by winning the competition to become eligible for Smart City Mission (SCM), immense development in terms of improving civic life and infrastructure is expected to take place under the Corporation limits. The Warangal city has already selected for 'National Heritage City Development and Augmentation Yojana' (HRIDAY) and Atal Mission for Rejuvenation of Urban Towns (AMRUT) Scheme. While the Corporation limit is spread over 471 square kilometres, the jurisdiction of Kakatiya Urban Development Authority (KUDA) extends to 1,805 kilometres. Though cities under HRIDAY scheme are automatically selected under SCM, e-governance initiatives proposed by the Corporation, clean city drive and others helped the city get Smart City Mission, official sources informed. Speaking to The Hans India here on Thursday, Municipal Commissioner Sarfaraz Ahmad expressed pleasure over the GHMC getting selected for the Smart City Mission.

\section{Profile of Greater Warangal Municipal Corporation}

Warangal, which is the second biggest city in Telangana after Hyderabad in terms of size and history, is in fact much older than the State capital. Warangal has got a history of 1,200 years with a rich heritage left by Kakatiya rulers. The GWMC, KUDA and district administration would work together for a visible change. 'When a person enters the city, he or she should not feel like entering just another city. The place has to be developed a real Kakatiya City, it is what we visualise, Warangal as a 'City of Lakes', he said there are about 40 tanks in and outside the Corporation. There is a possibility to develop them as entertainment zones.

Warangal district is in the Indian state of Telangana. It is located 148 kilometres (92 mi) northeast of the state capital of Hyderabad and for administrative purposes comprises the Warangal, Hanmakonda and Kazipet areas. The city is included in Amrut project and smart city by central government. The city is known for its heritage and in late 2014 was included in the Government of India's proposed HRIDAY - Heritage City Development and Augmentation Yojana, along with eleven other Indian cities.A few months earlier, the national government listed it among the 100 proposed smart cities that will be eligible for additional investment to improve urban infrastructure and industrial opportunities. Warangal is the second fastest-growing city in Telangana state, after Hyderabad. After taking control of 42 gram panchayats, its population has exceeded 1 million and this growth, plus its historical significance, caused the government to authorize the prefer Greater to the name of Warangal Municipal Corporation in early 2015.Warangal has been chosen as one of the heritage cities for HRIDAY - Heritage City Development and Augmentation Yojana scheme of Government of India

The establishment of Dist. and Regional Offices, Medical and Regional Engineering Collages, and Kakatiya University, and also minor and major industries viz. Rice Mills, Oil mills, small scale industries, Beedi Factories, A.J. Textile Mill, has made Warangal the second most important and biggest city in Telangana region next to Hyderabad. (It is connected a link by Rail of this ancient city to the other towns of the State the network of roads laid and developed from time to time have added to it importance as a Commercial Centre).

Cabinet approved Warangal Municipal Corporation (WMC) as Greater Warangal Municipal Corporation. The State government has issued G.O. No. 99 declaring the Warangal Municipal Corporation (WMC) as Greater 
Warangal Municipal Corporation. Now the corporation will have Warangal, Hanamkonda, Kazipet cities and 42 villages of six mandals surrounding the district headquarters. Following the public demand, the process of creating Greater Warangal was initiated by the then Chief Minister N. Kiran Kumar Reddy in 2011 during his visit to launch the Kakatiya festival. However, it did not materialise.

Now, the much awaited GO has been released. Earlier, the Department of Panchayat Raj issued G.O. No. 102 delimiting the 42 merged villages. The population under Warangal Corporation limits which was said to be around 6.13 lakh, now with the 42 villages in the proposed GWMC - the population increased to about 8.2 lakh, a criteria needed for the 'Greater' tag. Now the Greater Warangal Municipal Corporation will have 58 divisions and an area of 409 square kilometres. It has 183 slums and five different types of roads with paved roads constituting 480 kilometres, and unpaved 1,129 kilometres. It has three summer storage tanks -- Waddepally, Dharmasagar and Bhadrakali to meet the drinking water requirements of population and 41 service reservoirs.

\section{Clean City Championship Campaign}

The programme was taken up by Warangal Municipal Corporation (WMC) as part of its solid waste management initiative. This is a first of its kind special drive organized in Andhra Pradesh. It was initiated by Ministry of Municipal Administration. Speaking after inaugurating the programme the minister appealed to the citizens to cooperate with the municipal staff and officials to make the programme a successful one.

He said the State government has been taking all steps to develop the tri-cities of Warangal-HanamkondaKazipet as greater Warangal Municipal Corporation. He promised to provide required funds for the development of the town. Municipal Commissioner explained the details of the programme. WMC have launched the programme at Waddepally area in Hanamkonda and interacted with public seeking their active role in the programme. It might be noted that about 450 municipal staff from 65 municipalities from different districts were taking part in the programme on trial basis. The campaign would be held for one week between October 10 and 17.

\section{Solid Waste Management}

Several meetings in this connection was held here create awareness among the concerned officials visited the town in the current week to review the arrangements. The solid waste management programme was aimed at improving sanitation, hygiene and public health. As part of the programme stress would be laid on the collection of dry and wet wastage separately. A team of three municipal staff would cover 500 households. The visiting municipal staff from outside the district would learn about the collection and management of dry and wet wastage separately during the one week programme.

The residents have to hand over dry and wet wastage separately after October 17 failure of which would attract a penalty of one rupee. Similarly, if any resident was found dumping the wastages in open ground and public places a penalty of Rs 500 would be levied, the officials informed.

To strengthen the solid waste management system, around 200 auto-rickshaws are being procured for garbage collection and they will be inaugurated during Independence Day celebrations. "The GWMC officials are finalizing proposals for expansion of roads, redesigning of traffic signals and would commence removal of the encroachments on drainage canals and footpaths by this month end. They have been instructed to look for alternate sites to relocate road-side vendors to ease traffic," a municipal department official told Telangana Today.

Another meeting with the mayors, chairpersons, district collectors, municipal commissioners and other elected representatives and officials is scheduled next week. The Minister will be briefed on the progress of the works and further development works will be taken up after obtaining his approval," the official said. He said that the government is keen on taking up infrastructure development works like development of parks, roads, markets, community halls and graveyards as they would improve the daily lives of citizens.

\section{Urban Poor - Warangal Municipal Corporation}

A majority of the slum households in Warangal are working as labourers. The slums lack infrastructure facilities such as roads, drainage, housing, electricity, basic education and health, etc. With the implementation of programmes like Swarna Jayanthi Sahari Rozgar Yojana (SJSRY), the community based organizations like 
neighborhood groups and neighborhood committees have taken roots and they have been participating in the poverty alleviation and other development programmes effectively.

Spread of slums across the city is contributing to unhygienic environment in terms of cleanliness, water stagnation, presence of vectors, etc., which increases vulnerability towards deceases. Living conditions of the poor have consistently deteriorated due to several factors like inadequate environmental infrastructure and basic services.

\section{Rajiv Awas Yojana}

Rajiv Awas Yojana (RAY) for the slum dwellers and the urban poor envisages a 'Slum-free India' through encouraging States/Union Territories to tackle the problem of slums in a definitive manner. It calls for a multipronged approach focusing on

1. Bringing existing slums within the formal system and enabling them to avail of the same level of basic amenities as the rest of the town

2. Redressing the failures of the formal system that lie behind the creation of slums, and

3. Tackling the shortages of urban land and housing that keep shelter out of reach of the urban poor and force them to resort to extra-legal solutions in a bid to retain their sources of livelihood and employment.

The President of India, in an address to the Parliament stated that, "The scheme for affordable housing through partnership and the scheme for interest subsidy for urban housing would be dovetailed into the Rajiv Awas Yojana which would extend support under JNNURM to states that are willing to assign property rights to people living in slum areas. The Government's effort would be to create a slum free India in five years through RAY." The Ministry has already launched the "Slum-free City Planning" scheme for undertaking various preparatory activities such as slum surveys, Geographical Information System (GIS) mapping of such clusters, preparation of slum free city and State Plans.

\section{Survey of all slums - notified and non-notified}

During this stage, delineation of the areas under slums will be undertaken along with demographic and social profiling of the slum dwellers. The most important information gathered during this stage of the study would be the type of housing in the slums (Katcha or Pucca). The survey would also include data gathering about several important parameters like land ownership pattern (patta or encroachment), Land use and FSI pattern; Adequacy of physical infrastructure facilities like water supply, sewerage, drainage, solid waste management system, roads, electricity etc. Yet another important parameter that would emerge from this survey is the tenurial pattern of the dwellers. Lastly, the social infrastructural facilities like education, health, banking, community hall, livelihood centres would be covered in the survey.

\section{Mapping of slums using the state-of-art technology}

All the slums are to be mapped using GIS technology with detail filling through total station survey. Satellite images will be used, as appropriate in order to generate the base map of the city/slum under consideration. In this stage the data collection in steps and above is integrated in to a single entity using GIS platform. This will enable ushering of greater accessibility and transparency thereby making the entire exercise responsive to public needs. At this stage the selection of development model for the slums is to be taken up. The choice of the model may be Public-Public Partnership model or public-private partnership model.

\section{Conclusions}

The Greater Warangal Municipal Corporation implementation strategy consists of three components: Prioritization, phasing and measures for preventing future growth of slums. The first two components are important because the scheme extends for a period of five years and the total slums in the city have to be taken up under the scheme for development in a phased manner. With Warangal attracting more tourists than the capital city of Telangana, the Tourism Department is all set to prepare the district and its heritage sites to fit the Unesco bill. In Warangal, a variety of sites ranging from Mughal architecture to Kakatiya single stone structures can be showcased, said tourism officials on the sidelines of national conference on strategic development opportunities in tourism and hospitality industry held at National Institute of Tourism and Hospitality Management (NITHM). Telangana State Tourism Development Corporation (TSTDC) is currently in the process of setting up cottages near Laknavaram lake and also developing Ramappa lake. Smart city concept can be used for transforming any city into a smart city. Smart city have various overwhelming benefits $\&$ it a win -win situation for both, government \& the citizens. 


\section{References}

[1] Anuj Tiwari and Dr. Kamal Jain, "GIS Steering Smart Future for Smart Indian Cities." International Journal of Scientific and Research Publications, Volume 4, Issue 8, August 2015.

[2] Sejal S. Bhagat, Palak S. Shah and Manoj L. Patel, "Smart cities in context to Urban Development." International Journal of Civil, Structural, Environmental and Infrastructure Engineering Research and Development, Volume 4, Issue 1, February 2014, 41-48

[3] Charbel Aoun, "The Smart city Cornerstone: Urban Efficiency. "Schneider Electric White Paper, 2013

[4] Raman, Veena (2008) : Examining the ' $e$ ' in government and governance: A case study in alternatives from Bangalore City, India in Journal of Community Informatics Vol 4 No 2, 2008

[5] TCS (2015): White Paper on E governance initiatives in India

[6] Rodríguez-Bolíva, 2015, Transforming City Governments for Successful Smart City

[7] T.M. Vinod Kumar, 2013: Geographic Information Systems for Smart Cities. Ghaziabad : Copal Publishing Croup

[8] Ministry of Urban Development, 2014: Urban and Regional Development Plans Formulation And Implementation, Volume 1, Draft Report Version, 44-60.

[9] A Report on Development activities of Kakatiya Urban Development Authority, 1982-85.

[10] Annual Administration Reports of Kakatiya Urban Development Authority, Warangal. 1982-83, 1983-84, 19845-85, 1985-86, 1988-89, 1989-90. 2013-14.

[11] Report on Developmental Activities in Warangal Municipal Corporation 2013-2014.

[12] Area Plan Report from Kakatiya Urban Development Authority, Warangal.

[13] Report of the Committees of Boundaries Reforms in Municipal Administration, Government of India, New Delhi, 1974.

[14] Report of the Committee on the training of Municipal Employees, Ministry of Health, Government of India, 1963.

[15] Report of the Committee of Ministers on Augmentation of Financial Resources of Urban Local Bodies, Ministry of Health, Central Council of Land Self Government, 1963.

\section{Websites}

[1] http://indiansmartcities.in/Site/about.aspx

[2] http://telangana.municipalities.org 